\title{
Prevalence and zoonotic aspects of small ruminant mange in the lateritic and waterlogged zones, southern Benin
}

\author{
Prevalência e aspectos zoonóticos de sarna em pequenos \\ ruminantes em áreas de solo laterítico e alagados no sul do Benin \\ Sahidou Salifou ${ }^{1}$; Sabbas Attindéhou ${ }^{1 *}$; Chakirath Folakè Arikè Salifou ${ }^{1}$; Louis-Joseph Pangui ${ }^{2}$ \\ ${ }^{1}$ Laboratoire de Recherches en Biologie Appliquée - LARBA, Ecole Polytechnique d'Abomey-Calavi, \\ Université d'Abomey-Calavi - UAC, Cotonou, Benin \\ ${ }^{2}$ Ecole Inter-Etats des Sciences et Médecine Vétérinaires - EISMV, Dakar, Sénégal
}

Received August 26, 2012

Accepted February 1, 2013

\begin{abstract}
An epidemiological survey was undertaken from March to September 2010 to assess the prevalence and zoonotic aspects of scabies in small ruminants in two agro-ecological zones in southern Benin. Small ruminant $(n=444)$ smallholders and 1,807 of their animals (1,233 West African dwarf goats and 574 West African dwarf sheep) were included in the study. The animals underwent physical examination and, when scabies-like lesions were found, crusts and integument scrapings were collected for microscopic parasitological tests. The samples collected in each survey were coded in accordance with the owner-animal pairings in order to assess the degree of correlation between mange cases in humans (smallholders) and their animals. The overall prevalence of scabies was $28.33 \%$ and $9.5 \%$ in animals and smallholders (human cases) respectively. Infestations were significantly ( $\mathrm{p}<0.001)$ more frequent in goats $(39.6 \%)$ than in sheep. The uniqueness of the etiological agent (Sarcoptes scabiei), the very high predictive value of human scabies in infected farms (83.67\%) and a very high odds ratio $(\mathrm{OR}=2,019.25)$ indicate that small ruminant scabies has been transmitted to smallholders by their animals. Close contact between these smallholders and their animals was a determining factor in this interspecies communicability of sarcoptic mange.
\end{abstract}

Keywords: Small ruminants, smallholders, scabies, zoonosis, Benin.

\section{Resumo}

Um estudo epidemiológico foi realizado entre março e setembro de 2010, a fim de determinar a prevalência e aspectos zoonóticos de sarna em pequenos ruminantes em duas zonas agroecológicas no Sul de Benin. Pequenos criadores $(n=444)$ de ruminantes e 1.807 dos seus animais $(1.233$ cabras e 574 ovelhas Djallonké) fizeram parte da amostra para o estudo. Os animais foram submetidos a um exame físico e, quando detectadas algumas suspeitas de lesóes da sarna, crostas e amostras cutâneas foram colhidas para exames parasitológicos por microscopia de luz. As amostras colhidas em cada inquérito foram codificadas tendo como referência os donos dos animais, a fim de estabelecer/avaliar o grau de correlação entre os casos de incidência nos humanos (criadores) e os seus respectivos animais. A prevalência de sarna foi, respectivamente, 28,33\% em animais e 9,5\% entre os criadores (casos humanos). Infestaçóes foram significativamente $(\mathrm{p}<0,001)$ mais comum em caprinos $(39,6 \%)$ do que nos ovinos $(4,2 \%)$. A particularidade do agente etiológico (Sarcoptes scabiei), o alto valor preditivo de infestação nos humanos (83.67\%) e o elevado valor da odds ratio $(\mathrm{OR}=2019.25)$ indica um caráter zoonótico da sarna dos pequenos ruminantes. A proximidade entre homens e animais neste meio é um fator importante neste contato interespecífica da sarna sarcóptica.

Palavras-chave: Pequenos ruminantes, pequenos criadores, sarna, zoonose, Benin.

\footnotetext{
*Corresponding author: Sabbas Attindéhou

Laboratoire de Recherches en Biologie Appliquée - LARBA,

Ecole Polytechnique d'Abomey-Calavi,

Université d'Abomey-Calavi - UAC, Bénin. 01 BP. 2009 Cotonou, Benin

e-mail: sabbastino@yahoo.fr
} 


\section{Introduction}

Small ruminant farming is widely practiced by people in southern Benin (DOSSA et al., 2007). It provides cash income and represents important socioeconomic security. In most agroecological zones in southern Benin, West African Dwarf goats are free from taboos and dominate the livestock population (DOSSA et al., 2008). The herd size often stays under 10 heads per household or breeding unit. In waterlogged areas, food cropping and fishing are the most important economic activities. Sheep and goat production is a somewhat secondary interest with limited or complete absence of animal healthcare, which leaves the livestock at almost constant risk of pests. Gastrointestinal parasites and scabies are the two diseases of greatest impact on the evolution of production (PANGUI, 1994). Previous studies (SALIFOU et al., 2003) showed that the livestock management system in the studied area favored the incidence of scabies both in animals and in humans. The very close coexistence between owners and small ruminants could obviously play an important role in zoonotic transmission, but no evidence in this regard has ever been provided. This study aimed to estimate the prevalence of scabies in small ruminants in parallel with their owners affected by the same disease, in order to establish a possible correlation between human and animal cases in southern Benin.

\section{Materials and Methods}

\section{Study period and zone}

The study was conducted from March to September 2010 in two agro-ecological zones (AEZ) of Benin: the lateritic and waterlogged areas in southern Benin between latitudes $6^{\circ}$ and $7^{\circ}$ North and longitudes $1.5^{\circ}$ and $2^{\circ}$ West (Figure 1). Ten districts (Houyogbé, Djakotomey, Klouékanmè, Dogbo and Toviklin in the lateritic area and Athiémé, Bopa, Comé, Grand Popo, and Lokossa in the waterlogged area) were targeted. This study zone is characterized by a Guinean climate with two rainy seasons (April to July and September to November), temperature generally higher than $26.5^{\circ} \mathrm{C}$ and $75 \%$ humidity. The rainfall ranges from 900 to 1300 mm (AGBAHUNGBA et al., 2001).

\section{Sampling and parasitological examination}

The study consisted of a structural survey coupled with parasitological examination of small ruminant breeders. It aimed to establish the types of livestock or household units through direct interviews directed towards collecting structural information (on livestock and habitats), organizational information (monitoring of livestock health and identification of the person in charge) and information on closeness of contact between humans and animals. The presence of pets, including dogs, was investigated. According to Chermette (1991), dogs are the main source of zoonotic scabies. Questions on the sanitary status of the smallholdings (units) were also incorporated in the questionnaire. The parasitological survey was done by means of observation and direct measurement of lesions. The heads of household included in the survey were asked whether one or more members of their family were suffering from any skin disease. If the answer was positive, after obtaining the individuals' free consent, samples were then collected from animals and humans by lesions scraping. The single use sampling kits consisted of scalpels and plastic packaging with a writable face. Identification data (unit number, herd size, level of closeness to humans, extent of lesions and parts of the body) were listed on the packaging. The human and animal samples from the same investigation unit were coupled by means of an identification code. The scrapings were then sent to the Parasitology Laboratory of the Polytechnic School of Abomey-Calavi, where they were stored at $4{ }^{\circ} \mathrm{C}$ for three days at most. A crust lifted off each sample with tweezers was triturated in a drop of lactophenol on a microscopic slide and then covered with a cover slip. This preparation was observed under a light microscope with $10 \mathrm{X}$ objective. In some cases, the sample was first treated with a solution of $10 \%$ potassium hydroxide to facilitate detection of parasitic elements. Morphoanatomical diagnosis keys provided by Soulsby (1982) and Pangui (1994) were used to identify the scabies agents. A survey unit was declared to be infested if at least one of the samples revealed the presence of scabies agents.

\section{Statistical Analysis}

The prevalence rate of scabies was calculated by dividing the number of individuals affected by the number of subjects examined. The Z-tailed test was used in the Statistica software (single-user version 6.0, 2002) to determine the significance of differences between infection rates obtained during the study. The positive predictive value (PPV) of human cases when the small
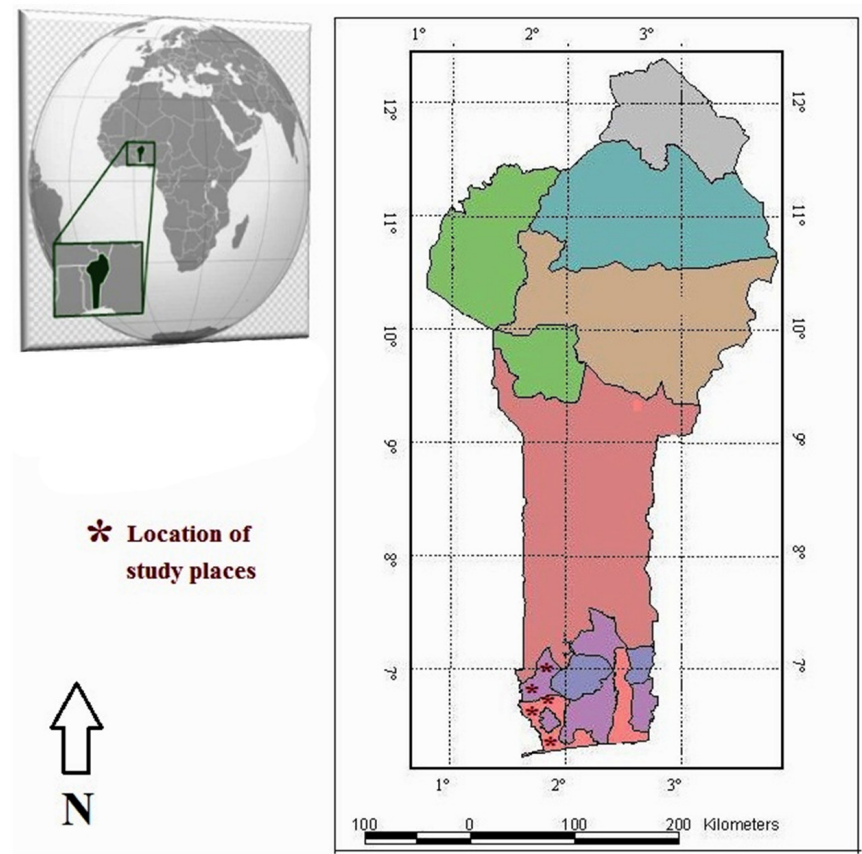

Figure 1. Location of studied, Benin, West Africa. 
ruminant flock was infected was calculated to estimate the level of infectiousness among the species. This value was calculated by means of the formula: PPV $=100 \times$ Number of affected households / Number of affected farms. A household was declared to be infected when at least one member of the family was suffering from scabies. A livestock herd was considered to be infected when at least one goat or sheep in the herd was infected.

\section{Results and Discussion}

\section{Prevalence and physical location of crusting}

Out of the 1,807 animals examined, 540 presented scabs, roundish areas and hyperkeratosis and pruritic manifestations reinforced the suspicion of scabies. These lesions were located in various parts of the body and were often generalized covering more than $50 \%$ of body surface in goats (Figure 2 ). These lesions showed different occurrence considering the anatomical regions where the lesions happened. The head (snout, ears and chamfer) was the body region most affected (Figure 4). In human cases, the lesions were usually localized (Figure 3), been more frequently reported in the feet, belly and back (Figure 5). The human cases were probably due contamination from animal origin. It is known that despite the host specificity of mange agents, interspecies transmission is possible (CHERMETTE, 1991; PANGUI, 1994). Transmission of mange to humans is due to the close contact between human and livestock.

\section{Etiology and prevalence of scabies}

Microscopic examination revealed that a single mite species was involved in both the animal and the human cases of scabies. This was Sarcoptes scabiei. This mite of the Sarcoptidae family (SOULSBY, 1982) was previously reported by Salifou et al. (2004)

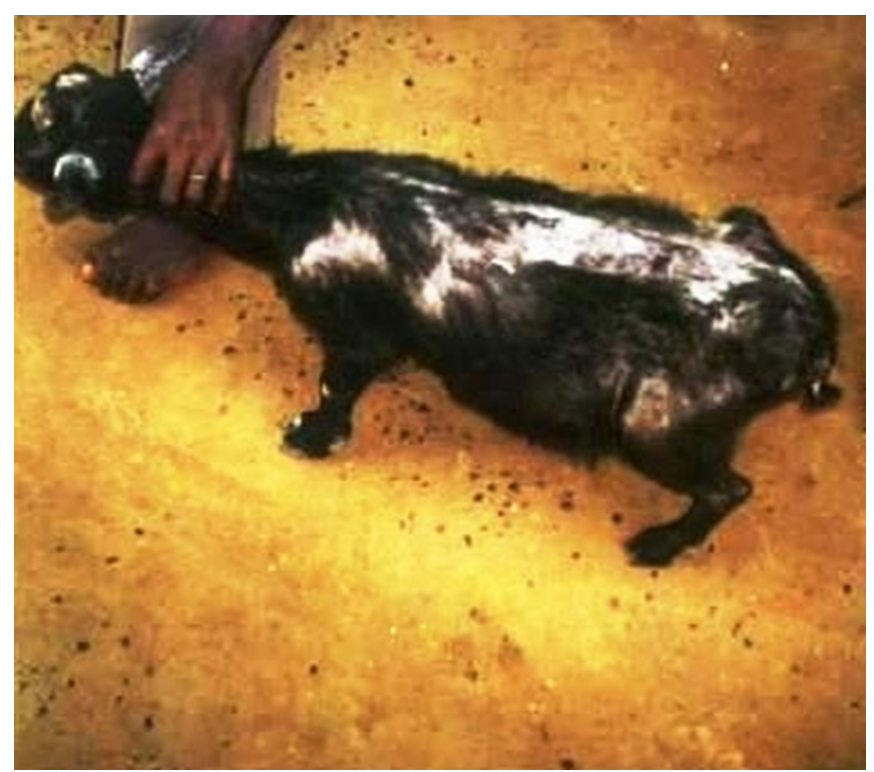

Figure 2. Generalized mange lesions in goat, from Benin, West Africa.

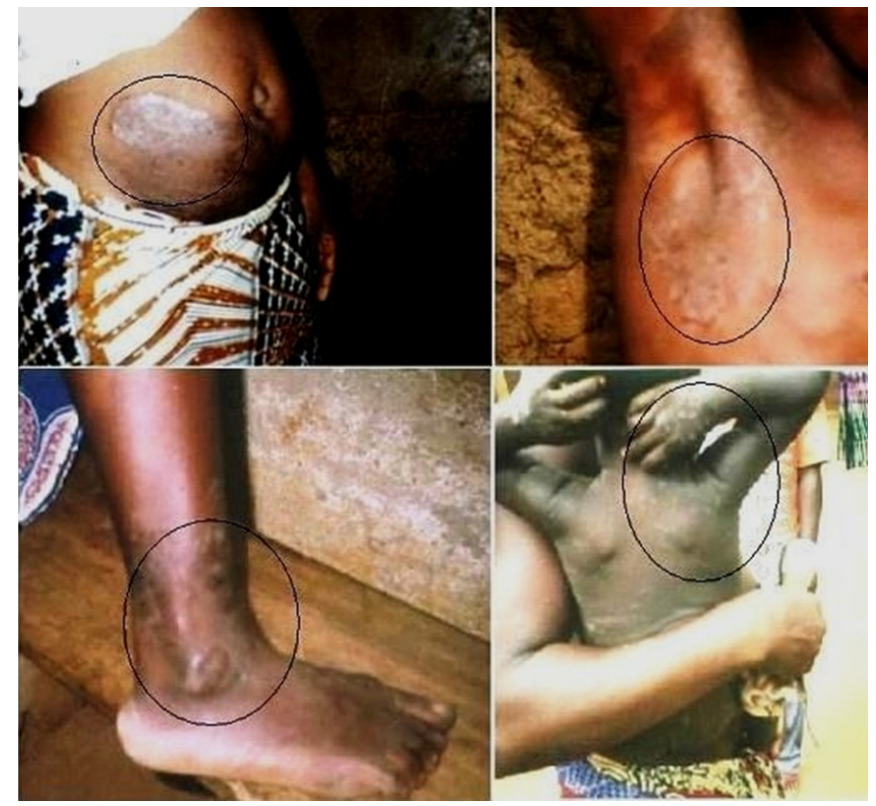

Figure 3. Localized lesions in humans, from Benin, West Africa.

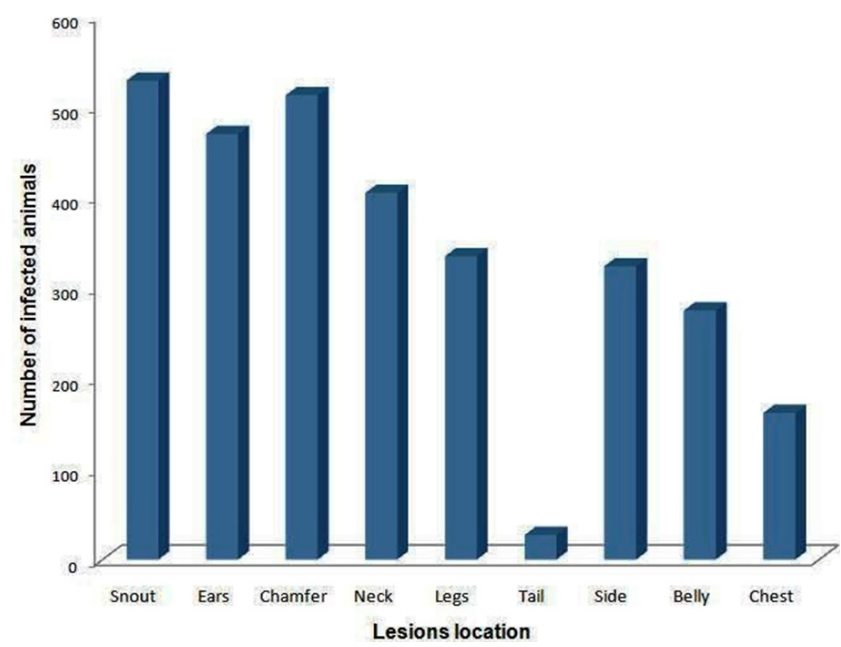

Figure 4. Incidence of scabies according to locations of lesions on the animals' bodies, from Benin, West Africa.

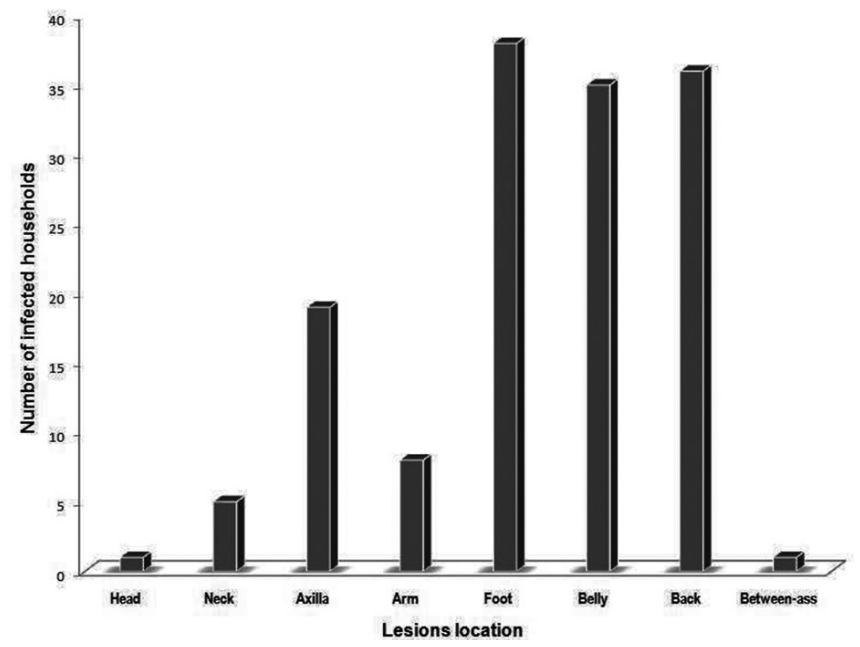

Figure 5. Incidence of scabies according to locations of lesions on the human body, from Benin, West Africa. 
Table 1. Prevalence of scabies in small ruminants and in humans, from Benin, West Africa.

\begin{tabular}{|c|c|c|c|c|c|c|}
\hline Species & $\begin{array}{c}\text { Number of subjects } \\
\text { examined }\end{array}$ & $\begin{array}{c}\text { Number of crust } \\
\text { carriers }\end{array}$ & $\begin{array}{c}\text { Number of parasite } \\
\text { samplings }\end{array}$ & $\begin{array}{c}\begin{array}{c}\text { Number of infected } \\
\text { subjects }\end{array} \\
\end{array}$ & $\begin{array}{c}\text { Infection rate } \\
(\%)\end{array}$ & $P$ \\
\hline Goats & 1,233 & 510 & 510 & 488 & $39.6^{a}$ & \multirow{4}{*}{0.000} \\
\hline Sheep & 574 & 30 & 30 & 24 & $4.2^{\mathrm{b}}$ & \\
\hline Total number of animals & 1,807 & 540 & 540 & 512 & $28.3^{\mathrm{c}}$ & \\
\hline Humans & 444 & unknown & 42 & 42 & $9.5^{\mathrm{d}}$ & \\
\hline
\end{tabular}

to be a parasite of small ruminants in the Atlantic area of southern Benin. Another study reported the presence of another kind of mite, Psoroptes, in the region of Northern Couffo (KOUDANDÉ, 2006). The results from the present study indicate that the overall prevalence of sarcoptic mange in small ruminants was of $28.3 \%$ (Table 1). This is a high prevalence that can be explained by the farming method characterized by a definite lack of hygiene in the community. This prevalence is very similar to what was reported $(30 \%)$ by Salifou et al. (2003), being in agreement with the view of some West African authors who reported high incidence of sarcoptic mange (DIA; DIOP, 2005). Prevalence index between 11 and 33\% were reported in Nigeria (NWOHA, 2011). In Ethiopia, which is a less humid country, much lower prevalence $(3.98 \%)$ was recorded by Sheferaw et al. (2010). This large difference might be explained by climatic factors but also by herd management. The prevalence of scabies infestation was significantly higher $(P<0.05)$ in goats $(39.6 \%)$ than in sheep $(4.2 \%)$. This is consistent with the epidemiology of the scabies agent, which is deemed to be more pathogenic in goats (reference). The prevalence of scabies among livestock keepers was about 9.5\%. It can be presumed that this prevalence rate relates only to apparent infestation, being certainly undervalued. In fact, several small ruminant owners investigated in this study were very annoyed and embarrassed by questions relating to possible presence of scabby lesions. These people (generally adults and men in particular) were reluctant to be examined at the interview stage, making it was not possible to include them in the parasitological survey. The majority of the individuals sampled $(73.81 \%)$ were children under 15 years of age. Since systematic physical examination was not possible, a sizeable proportion of false negatives had to be taken into consideration. During the survey, was observed that only two households among the population owned a dog.

\section{Correlation between human and animal scabies}

In terms of surveyed units, sarcoptic mange affected 11.04\% of the farms (Table 1) and $9.45 \%$ of the households (Table 2). The contingency analysis revealed a very high positive predictive value $(83.67 \%)$ for human cases with an infected herd, with a very high odds ratio $(\mathrm{OR}=2,019.25)$. These results suggested that there is a significant correlation between suspected human cases and these animals. The absence of contact with pets (dogs) in most cases, the confinement of the animals, and the very close contact between the animals and the small livestock holders (because of fear of theft, the owners of the goats and sheep spent their nights in the stalls with their animals) reinforced the potential for transmission of scabies agents from goat or sheep to humans. The
Table 2. Contingency table for scabies infection in the units surveyed.

\begin{tabular}{lccc}
\hline & \multicolumn{2}{c}{ Human scabies } & \multirow{2}{*}{ Total } \\
\cline { 2 - 3 } & Positive & Negative & \\
\hline Infected livestock & 41 & 8 & 49 \\
Uninfected livestock & 1 & 394 & 395 \\
Total & 42 & 402 & 444 \\
& \multicolumn{2}{c}{ OR=2,019.25 } & \\
\hline
\end{tabular}

uniqueness of the pathogen (Sarcoptes scabiei var capri) provides further evidence for cross-transmission. Some records of extensive lesions in humans contradict the notion that sensitivity to scabies agents should remain specific even if interspecies transmission is possible (PANGUI, 1994). Children, the class of individuals most affected in the present study, were in fact in even closer contact (playing games and sleeping in the same stalls) with goats and were less likely to practice good personal hygiene.

\section{Conclusion}

This study revealed high prevalence of scabies in the lateritic and waterlogged zones of southern Benin. This disease with important health and economic consequences needs to be duly considered in development of prophylactic guidelines. This study also showed the highly zoonotic nature of small ruminant scabies in the study area, clearly raises the issue of the impact of cropping patterns and herd management on public health in Benin.

\section{Acknowledgements}

The authors thank the small livestock holders and also the heads of villages in the study area for their good spirit of cooperation and support.

\section{References}

Agbahungba G, Sokpon N, Gaoué OG. Situation des Ressources Génétiques Forestières du Bénin. In: Annali Atelier sous-régional FAO / IPGRI / ICRAF sur la conservation, la gestion, l'utilisation durable et la mise en valeur des ressources génétiques forestières de la zone sahélienne; 1998; Ouagadougou. Rome: FAO; 2001. Note thématique.

Chermette R. Rôle des animaux de compagnie dans la dispersion des zoonoses d'origine parasitaire. Rev Sci Tech Off Int Epiz 1991; 10(3): 693-732. 
Dia ML, Diop C. Etude comparative de l'efficacité clinique et parasitologique de trois formulations injectables à base d'ivermectine dans le traitement de la gale sarcoptique du mouton. Revue Méd Vét 2005; 156(2): 87-90.

Dossa LH, Rischkowsky B, Birner R, Wollny C. Socio-economic determinants of keeping goats and sheep by rural people in southern Benin. Agric Hum Values 2008; 25(4): 581-592. http://dx.doi. org/10.1007/s10460-008-9138-9

Dossa LH, Wollny C, Gauly M. Smallholders perceptions of goat farming in Southern Benin and opportunities for improvement. Trop Anim Health Prod 2007; 39(1): 49-57. PMid:17941487. http://dx.doi.org/10.1007/ s11250-006-4440-2

Koudandé OD. Lutte contre la gale des chèvres en milieu villageois au Sud-Bénin. Bull Recherche Agron Bénin 2006; 51:12-19.

Nwoha RIO. A case report on scabies in a goat. Clin Rev Opinions 2011; 3(5): 51-54.
Pangui LJ. Gales des animaux domestiques et méthodes de lutte. Rev sci tech Off int Epiz 1994; 13(4): 1227-1247.

Salifou S, Hessa CC, Pangui LJ. Enquête préliminaire sur les acariens et les insectes parasites des petits ruminants dans les régions de l'Atlantique et du littoral (Sud-Bénin). Revue Méd Vét 2004; 155(6): 343-346.

Salifou S, Houessou MR, Doko SY, Pangui LJ, Toguebaye BS. Gale des petits ruminants dans le Sud-ouest du Bénin: étude parasitoclinique, impact socio-économique et influence sur la santé des éleveurs. RASPA 2003; 1(2): 122-127.

Sheferaw D, Degefu H, Banteyirgu D. Epidemiological study of small ruminant mange mites in three agro-ecological zones of Wolaita, Southern Ethiopia. Ethiop Vet J 2010; 14(1): 31-38.

Soulsby EJL. Helminths, arthropods and protozoa of domesticated animals. 7th ed. Baillière: Tindal \& Cassel; 1982. PMCid:370254. 